USBAD Uluslararası Sosyal Bilimler Akademi Dergisi -

International Journal of Social Sciences Academy, Yıl 3,

Year 3, Sayı 5, Issue 5, Nisan 2021, April 2021.

e Issn: 2687-2641

\title{
ARAP BAHARI ÖNCESİ VE SONRASINA YÖNELİK TÜRK DIŞ POLİTİKASI: TUNUS, MISIR, BAHREYN VE YEMEN ÖRNEĞİ
}

TURKISH FOREIGN POLICY BEFORE AND AFTER THE ARAB SPRING:

THE EXAMPLE OF TUNISIA, EGYPT, BAHRAIN AND YEMEN

\section{Cemaleddin GÜVENÇ}

Yüksek Lisans Öğrencisi, Siyaset Bilimi ve Kamu Yönetimi Siyaset ve Sosyal

Bilimler Bölümü, Hitit Üniversitesi,

Çorum/Türkiye.

Graduate std., Political Science and Public Administration Department of Political and Social Sciences, Hitit University,

Corum/Turkey.

190135047@ogrenci.hitit.edu.tr

ORCID ID: 0000-0003-4494-2449

\section{Makale bilgisi | Article Information}

DOI: $10.47994 /$ usbad. 814778

Makale Türü / Article Type: Araştırma Makalesi / Research Article

Geliş Tarihi / Date Received: 22.10.2020

Kabul Tarihi / Date Accepted: 04.03.2021

Yayın Tarihi / Date Published: 20.04.2021

Yayın Sezonu / Pub Date Season: Nisan / April

Bu Makaleye Atıf İçin / To Cite This Article: Güvenç, C. (2021). Arap Baharı Öncesi ve Sonrasına Yönelik Türk Dış Politikası: Tunus, Mısır, Bahreyn ve Yemen Örneği. USBAD Uluslararası Sosyal Bilimler Akademi Dergisi 3(5), 354-381.

İntihal: Bu makale intihal.net yazılımınca taranmıştır. İntihal tespit edilmemiştir.

Plagiarism: This article has been scanned by intihal.net. No plagiarism detected.

\section{intihal.net}

İletişim: Web: https://dergipark.org.tr/tr/pub/usbad

mail: usbaddergi@gmail.com 
Öz: Arap Baharı 21. yüzyılın en önemli olaylarından biri olarak tarih sahnesinde yerini almıştır. Arap Bahar'ının bölge ve dünya ülkeleri üzerinde ticari, siyasi, sosyal ve kültürel birçok etkisi bulunmaktadır. Bu çalışmada ilk olarak Arap Baharının yaşandığı bölge olan Ortadoğu bölgesinden bahsedilmiş, Arap Baharını yaşayan ülkelerden Tunus, Mısır, Bahreyn ve Yemen üzerinden tarihsel süreçleriyle Arap Baharının analizi bu ülkeler üzerinden aktarılmıştır. Arap Baharından etkilenen ve etkisini gösteren Türkiye'nin bahse konu ülkeler üzerinden Türk dış politikasının yansımalarının avantajları ve dezavantajları üzerine değerlendirmeler yapılmıştır. Sonuç olarak; Türkiye Arap Baharı sonrasında Ortadoğu'daki bazı ülkelerinin kendisine has özellikleri göz önünde bulundurularak ortaya koyduğu dış politikasıyla demokrasi yolunda ilerlemeleri açısından başarılı neticeler elde etmiş, bazı ülkelerin kendine özgü koşulları göz ardı edildiğinden olumlu neticelere varılamamıştır. Nihayetinde Türk dış politikasında siyasi gerginliklerden, ekonomik, bilimsel, kültürel ve rasyonel gerçekliklere ulaşıldığında Ortadoğu bölgesinde aktif bir rol sahibi olabileceği tezi ortaya koyulması amaçlanmaktadır.

Anahtar Kelimeler: Ortadoğu, Türkiye, Dış Politika, Arap Baharı, Demokrasi

Abstract: 21 Arab Spring. It has taken its place on the historical stage as one of the most important events of the century. The Arab Spring has many commercial, political, social and cultural effects on the countries of the region and the world. In this study, the Middle East region, the region where the Arab Spring took place, was mentioned for the first time, and the analysis of the Arab Spring with its historical processes through Tunisia, Egypt, Bahrain and Yemen from the countries that experienced the Arab Spring was transmitted through these countries. Turkey, which has been affected by the Arab Spring and has shown its influence, has been assessed on the advantages and disadvantages of the reflections of Turkish foreign policy on the bet countries. As a result, some countries in the Middle East after the Arab Spring turkey, considering its own unique features revealed, foreign policy, in terms of progress towards democracy are ignored because the specific conditions of some countries that have achieved successful results had been obtained positive results. Finally, it is aimed to put forward the thesis that it can have an active role in the Middle East region when political tensions, economic, scientific, cultural and rational realities are reached in Turkish foreign policy.

Keywords: Middle East, Turkey, Foreign Policy, Arab Spring, Democracy

\section{GİRİ̧̧}

Arap Baharı, Tunus'ta başlamış Kuzey Afrika ve Ortadoğu ülkelerinin tamamına yakınında önemli bir etki alanı yaratmıştır. Tunus ve Mısır'da diktatör idarecilerin yönetimden el çektirilmesine, Bahreyn'de Batılı ülkeler ve körfez ülkelerin himayesinde diktatör yönetimin isyanı bastırmasına ve Yemende iç savaşın devam etmesiyle sonuçlanmıştır. Batılı devletler, Ortadoğu bölgesindeki enerji kaynaklarına sahip olma isteği bu bölgenin vazgeçilmez stratejik önemini ifade etmektedir. Bölge, petrolde olduğu gibi 
dünya doğalgaz rezervlerinin yarısına yakınına da sahiptir. Ortadoğu tarihi açısından Arap Baharı ayrı bir önem taşımaktadır. Arap Baharı, batılı ülkelerin yenidünya düzeni gayesiyle I. Dünya Savaşı'ndan günümüze planlarının bir parçasıdır (Sarp ve Cihan, 2020: 7,8; Turhan, 2012: 259; Yılmaz, 2016: 101).

Türkiye, bölgede jeopolitik ve jeostratejik bir konuma sahiptir. Tarihi köklü geçmişi, demokratik-laik yapısı, anayasal düzene bağlı bir hukuk devleti olması ve Müslüman kimliğinin bulunması nedeniyle bölgede model ülke olunabilecek bir konumdadır. Özellikle Ak Partinin 2002 yılında iktidara gelmesi ve Arap ülkeleriyle diplomasi trafiğini ticari, siyasi, kültürel ve sosyal olarak arttırmasıyla birlikte Arap ülkelerinin Türkiye'ye karşı bakış açılarının olumlu yönde değişmesine sebebiyet vermiştir. Arap Bahar'ının başlamasıyla beraber Türk dış politikasının, bölgeye yönelik genel yaklaşımı, halk ayaklanmalarının yanında yer alması ve diktatör rejimlerin yönetimi devretmesi yönlüdür. Fakat Arap Baharı sonrasında yaşanan siyasi gelişmeler ile beraber Türkiye'nin Tunus, Mısır, Bahreyn ve Yemen'e yönelik dış politikasında farklı yaklaşımlar sergilediği görülmektedir. Türkiye'nin bahsi geçen bölge ülkelerine yönelik bu tutumu, kimi zaman bölgede yalnız kalmasıyla ittifak arayışlarına girmesine kimi zaman da Arap Bahar'ını yaşayan ülkenin diktatör rejimden, demokratik rejime yerleşmesine katkıda Sayfa | 356 bulunmuştur.

Bu çalışmada Ortadoğu'da yaşanan Arap Baharı öncesi ve sonrasında, Türkiye'nin Tunus, Mısır, Bahreyn ve Yemen örnekleri üzerinden olaylara bakış açısı ve yaklaşımı araştırmanın konusunu teşkil etmektedir. Bu noktadan hareketle; Türkiye, Arap Baharının başlamasıyla bölgede yaşanan gelişmelerde ortaya koyduğu politikayla ülke bazında farklı tutumlar sergilemesinin Türkiye açısından hangi siyasi sonuçlara sebebiyet verdiği ortaya konulması amaçlanmaktadır. Nitekim çalışmada, Arap Baharının yaşanmasıyla bölgede etkin rol alan Türkiye'nin ülkeler bazında karşılaştığı sorunlar ve olaylar irdelenmiş ve gelinen noktada bazı ülkelerle sorunların devam ettiği ifade edilmiştir. Nihai olarak Nitel yöntemin hâkim olduğu çalışmada Türkiye'nin bölgeye yönelik dış politika anlayışına değerlendirme ve yorumlama da bulunulmuş, ileriye yönelik Türk dış politikasının bölge üzerinde etkin rol sahibi olması yönlü katkı sağlanması hedeflenmektedir. 


\section{ORTADOĞU BÖLGESİ, ARAP BAHARININ ORTAYA ÇIKIŞI VE ÜLKELERINN TARİHSEL SÜREÇLERI}

\subsection{Ortadoğu Bölgesi}

Ortadoğu, jeopolitik konumu ve sosyo-kültürel özellikleriyle, uygarlıklar meydana getirmiş, medeniyete beşiklik etmiş ve uygarlık tarihini de ortaya çıkarmıştır. Ortadoğu, üç büyük dinin Yahudilik, İslamiyet ve Hıristiyanlığın doğup büyüdüğü ve dünyaya yayıldığı bölgedir. Din yönüyle yaşanan bu çeşitlilik mezhepsel anlamda da kendisini göstermektedir. İslamiyet'te Sünni ve Şii temelinde ayrılmakla kalmamış, misalen, Şiilik İsmaliye, Nusayri vb. çeşitlilik göstermiş olup, Hıristiyanlık ve Musevilikte de bu duruma rastlanılmaktadır. Bu farklııılar mezhebe yönelik çatışmaları da beraberinde getirmiştir. Ortadoğu, zengin petrol kaynaklarına sahip olduğundan hegemon devletlerin bu bölgede menfaat çatışmalarına sebebiyet vermiş, bölgenin siyasi ve yönetim olarak yeniden şekillenmesinin de kıvılcımlarını ateşlemiştir (Özdem, 2016: 6; Sakin ve Deveci, 2011: 285286).

\subsection{Arap Bahar'ının Ortaya Çıkışı}

Arap baharına geçmeden önce Arap Baharıyla yaşanan halk hareketlerini incelemek açısından dünyadaki toplumsal hareketlerin ve Sayfa|357 düşünürlerin tarihsel süreçlerine kısaca değinilmesi önem arz etmektedir.

Batıda 15. yüzyılda İngiltere'de başlayan toplumsal hareketler, 18. yüzyılın sonunda Fransa'da özgürlük hareketleriyle devam etmiş ve 19. yüzyılın başlarında Almanya'da dünyayı etkisi altına alan modernleşme hareketine dönüşmüştür (Güvenç, 2020a: 111). Dünyada özellikle Fransız Devrimi, sonraki toplumsal hareketler ve devrimler açısından ayrı bir önem taşımaktadır.

18. yüzyılın sonundan bahsedildiğinde ilk akla gelen şüphesiz Fransız Devrimi ve devrime ilham kaynağı olan filozoflardır. Mutlak monarşinin zorba yönetimi, burjuva sınıfların ayrıcalıkları, açlık ve sefil hayat süren halkın aşırıya dayanan vergi yükümlülükleri insanları bir arayış içerisine iteklemiştir. Dönemin Voltaire, Condorcet ve Rousseau fikir adamlarının eşitlik, özgürlük ve hükümet yönetimi gibi düşünceleri yoksul olan halk için devrime giden yolda bir umut ışığı olmuş, akabinde 1789 yıında da Fransız Devrimi gerçekleşmiştir. Bu devrim ve fikir adamlarından özellikle Rousseau sonraki insanlara ve devrimcilere de bu yönüyle ilham kaynağı olmuştur (Güvenç, 2020b: 65). Rousseau'nun devlet anlayışında; devlet, halkın bütününden meydana gelen, halkın iradesini yansıtan ve halktan ibaret olan halk devlet olarak da görülmektedir (Güvenç, 2020c: 105). Halkın 
ayaklanmasıyla yaşanan devrimler kapsamında ve bu bağlamda "Bahar" kavramı, Avrupa'da ilk defa 1830-1848 devrimleri sırasında kullanılmaya başlanmış ve ayrıca Soğuk Savaş son bulmaya başlarken SSCB'ye karşı isyan eden ve milli siyasi sınırların bağımsızlık mücadelesi için gayret gösteren hareketlenmeler bu yönde ifade edilerek milletlerin yeni ilkbaharı olarak isimlendirilmiştir. Bu benzeştirme sonucunda, Arap milleti hareketlerine de bahar kelimesi münasip görülmüş ve Arap Baharı olarak ifade edilmeye başlanmıştır (Çiçekçi, 2012: 16). Arap Bahar'ını, Ortadoğu'da baskı kuran ve otoriter idarecilere karşı yakın dönemde ortaya çıkan halk ayaklanmalarını göstermek ve süreci demokratikleşme hareketi olarak da tanımlayabiliriz. Arap Baharı, Ortadoğu Bölgesinde büyük bir dönüşüme yol açan, devletten devlete sirayet eden, milli çaptaki esaslı farklılıklara karşın, aynı slogan ve aynı isteklerle özgürlük, demokrasi, temel ve sivil hakları kapsayan bir harekettir. Arap Baharı, nasıl sonlanacağı bilinmeyen ve isimlendirilmesiyle de geniş yankı uyandıran yaşandığı coğrafyada deprem etkisi yaratan devasa bir harekettir (Duran ve Özdemir 2012: 185).

\subsection{Arap Baharını Yaşayan Ülkeler ve Tarihsel Süreçleri}

Arap Baharı öncesinde bölgenin en önemli özelliği mevcut yönetimlerin neredeyse tamamına yakınının demokratik olmayışlarıdır (Oğuzlu, 2011: 9). Bununla beraber, Sovyetler Birliğinin parçalanmasıyla meydana gelen demokrasi rüzgârına ayak uyduramayan Arap devletleri ile geri kalan dünya devletlerinin arasındaki demokrasi farklılıkları çok daha fazla belirgin hale gelmiştir (Koçak, 2012: 35). Arap devletlerinde halkların işsizlik, yoksulluk, gelir dağılımındaki adaletsizlik gibi nedenlerin yanında baskıcı yönetimlerden dolayı demokrasi de gelişme gösterememiştir (Paksoy vd., 2013: 177-178).

Ortadoğu'da meydana gelen halk ayaklanmaları ile birlikte, kimi ülkelerde mevcut yapı korunurken, kimilerinde ise kaos ortamının ve iç savaşın derinleşmesine sebep olmuştur (Cicioğlu ve Miş, 2013: 2). Bu bağlamda Tunus, Mısır, Bahreyn ve Yemen üzerindeki tarihsel sürece değinilmesi gerekmektedir.

Arap Baharının ilk kıvılcımı Tunus'ta bir gencin kendisini yakmasıyla başlamış, bu olayların ana nedenleri olan halkın açlık ve sefaleti, yoksulluğu, işsizliği, gelir dağılımındaki adaletsizlikler iyice bunalan halka yeniden diriliş için isyan hareketleri başlatmasına vesile olmuş, diktatör Zeynel Abidin Bin Ali rejimi devrilmiştir (Kaya ve Hasar, 2012: 9-12). Diğer ülkelerde Arap Baharı ile başarılamayan ve toplumun tüm kesimlerinin ortak ürününü 
yansıtan anayasa kabulü ile beraber Tunus'ta demokrasiye geçiş mümkün olmuştur (Anadolu Ajansı, 2017). Tunus'un ardından Arap Baharının sıçradığı diğer ülke de Mısır'dır. Tarih sahnesinde Mısır, 1953 yılında cumhuriyete geçmiş, fakat askerî yapı yönetimden hiçbir zaman vazgeçmemiş olup, Mısır yönetiminde otoriter ve baskıcı idarecilerin vesayetçisi Mısır ordusu olmuştur (Anadolu Ajansı, 2020). 25 Ocak 2011 yılında Tahrir Meydanında öfke gününde demokrasi çanlarının sesleri yankılanmış ardından özgür seçimler yapılmış Mursi seçimi kazanmıştır. Ancak Mursi'nin yaptıklarından veya yapacaklarından korkan muhalefet sokaklara dökülmüş Mursi taraftarları da sokağa dökülünce ortalık savaş alanına dönüşmüş, bunu fırsat bilen ve tarihteki görevini unutmayan iktidarın vesayetçisi Mısır ordusu yine yönetime el koymuştur (Bekâroğlu ve Kurt, 2015: 29). Arap Baharının yaşandığı diğer bir ülkede Bahreyn'dir. Tarihsel süreçte İngiltere'nin egemenliğinden kurtulup, 1971 yılında bağımsızlığını ilan etmiştir. Ülkenin çoğunluğunu Şiiler oluştursa da yönetim Sünni olan Al Khalife ailesindedir. Arap Baharı ile beraber Bahreyn'in başkenti Manama'da İnci Meydanında toplanan halk protestolara başlamış ancak Suudi Arabistan liderliğindeki Körfez İşbirliği Konseyi ülkedeki eylemleri şiddetli bir şekilde bastırmıştır. Bahreyn'de her zaman Suudi Arabistan ve İran gerginliği yaşanmaktadır. Arap Baharı Bahreyn'e demokrasiyi getiremediği gibi çatışmaların bitmesini de sağlayamamıştır (Örtlek, 2013: 269; Catovic, 2015: 8-18). 2011 yılının Ocak ayında başlayan ve yıl boyunca tesiri altına alan Arap Baharının yaşandığı diğer bir ülke de Yemen'dir. Başkent Sana'da başlayan gösterilen hızla diğer illere de yayılmıştır (Muslu, 2011: 328). Ülkedeki mezhep kavgası, iç savaş, Arap Baharı gösterileriyle Suudi Arabistan önderliğindeki körfez ülkelerinin olaylara müdahalesi, Suudi Arabistan ve İran arasındaki çekişme gibi nedenlerden ve kolera gibi salgın hastalıklardan dolayı Yemende tam bir insani felaket yaşanmakta, yaşanmaya da devam etmektedir. Bu nedenlerden ötürü Yemende Arap Baharı kışa dönüşmüştür (Gün, 2012: 125; Çelikkol, 2018).

\section{ARAP BAHARI ÖNCESİ VE SONRASINA YÖNELİK TÜRK DIŞ POLİTIKASI}

21. yüzyılda dünyanın küreselleşmesiyle, iletişim ve haberleşme imkânlarının fazlalaşmasıyla gelişmiş ülkelerin güzel ve ferah durumlarına bakan Arap Baharının yaşandığı Tunus, Mısır, Bahreyn, Yemen ve diğer maruz kalan ülkelerin halkları da huzursuzluklarını dile getirmeye başlamışlardır. Arap Baharında yaşanan gelişmelerde hususi bir yeri olan sosyal medya da bu gelişmelerin hızla yayılmasına ve insanların toplu 
hareket etmelerine yol açmıştır. Meydana gelen şiddetli isyanlar, zarara maruz kalan insanlar, kamu kurumlarının işlevsizlikleri, yıkılan iktidarlar, devrilen rejimlerle beraber tüm bu yaşanan gelişmeler Arap Baharının bir parçası haline gelmiştir. Geçmişten gelen bağları da düşünüldüğünde ekonomik, ticari ve kültürler ilişkiler sebebiyle Türkiye de bu süreçten etkilenmiştir. Evveliyatında Ortadoğu coğrafyasındaki insanlarla akrabalık bağları sürdüğünden dolayı en fazla etkilenme bu alanda olmuştur. Bununla beraber Arap Baharı sonrasında komşu devletlerde yaşanan sıkıntılı duruma karşı Türkiye kayıtsı kalmamış, milyonlarca insanı ülkesinde misafir etmiştir. Arap Baharı ile birlikte bu ülkelerle yapılan ithalat ve ihracat 0 ülkelerden gelen turistler, Türkiye'den o ülkelere yatırım amaçlı giden iş adamları, tüm bunlar birlikte düşünüldüğünde yaşanan kaos ortamından Türkiye olumsuz yönde etkilenerek ağır ekonomik kayıplar yaşamıştır. Türkiye Müslüman kimliğe ve demokratik bir rejime sahip olması, komşularıyla dini, akrabalık bağı ve insani ortak paydalarının olması 0 ülkelere model teşkil ettiği söylenebilir (Buzkıran ve Kutbay, 2013: 159160). Diğer yönden Türkiye'nin Soğuk savaş döneminde uyguladığı dış politikasında; batı ile bütünleşme hedefinin gerçekleştirilmesi, batı ve hususi olarak ABD'nin ekonomik yardımlarının beklenmesi, Yunanistan ve Kıbrıs problemlerinde ülke menfaatlerinin korunması, Sovyet tehdidinin uzaklaştırılması gayesi bulunmaktadır. Demokrat partinin dış politikada ana gayesi, batı ile bütünleşme çabası yatmaktadır. Bu dönemde Ortadoğu'ya yönelik politika inişli çıkışlı bir seyir göstermektedir. Soğuk Savaş dönemi sonrasında 1991-2001 yılları arasında Türkiye dış politikasında Avrupa Birliği ile bütünleşme, ABD stratejik ortaklığın ilerletilmesi, Orta Asya ve Rusya Federasyonu ile ilişkilerin kuvvetlendirilmesi, Ortadoğu'da meydana gelen gelişmeleri doğru okuyabilmek ve kendi menfaatlerinden geri atmamak ve Ortadoğu barış sürecine katkıda bulunma gayesi taşımaktadır (Akıllı, 2012: 41-43). Türkiye, geçmişten günümüze kadar olan süreçte dış politikasında hem Batı ile hem de Ortadoğu ile bağını koparmamıştır. Arap Baharıyla yaşanan sıkıntılı süreçte Türkiye göç, ticari, siyasi ve sosyal alanlarda ciddi şekilde zarar gördüğü söylenebilir. Fakat Türkiye'nin demokratik yapısı ve Müslüman kimliği bir bütün olarak düşünüldüğünde Ortadoğu coğrafyasına model ülke olma çabasında olduğu belirtilebilir.

\subsection{Arap Baharı Öncesi Türk Dış Politikasının Genel Durumu}

Türkiye, Soğuk Savaş sonrası dönem dış politikasında, bakış açısını genişletme fırsatı yakalamış, Soğuk Savaş zamanındaki pasif rolü yerine bu dönemde daha aktif bir politika izlemeye başlamıştır. ABD'de yaşanan 11 Eylül olayları döneminde ise Türkiye Ortadoğu'ya ilişkin dış politikasında 
giderek kendisine güvenen ve bunu her geçen gün daha da artıran bir ivme yakalamıştır. Türkiye maziye rağmen Ortadoğu ile kurduğu ve yeniden yeşertmeye çalıştığı hususi ilişkileri sebebiyle, bölgede cereyan eden gelişmelerde daha tesirli ve etkili bir oyun kurucu rolüne bürünmüş olup, Irak'ın 1990 tarihinde Kuveyt'i işgal etmesi, Türkiye'nin bu bölgeye nazarını farklılaştırmıştır. 1991 yılı mart ayında ortaya çıkan insani kriz ve Türkiye'ye mülteci akını sonrasında Madrid Barış Konferansı ile başlayan ve Oslo'da yeşeren Filistin problemine çözüm üretebileceğine olan görüşü, söz konusu değişime hız kazandırmıştır. Ak Partinin yönetime gelmesiyle Ortadoğu politikalarında değişim ve yakınlaşma, ivme ve belirginlik hâsıl olmuştur (Duran ve Özdemir, 2012: 184).

Ak Parti iktidarı ile birlikte Arap ülkelerinin Türkiye'ye karşı bakış açıları; Müslümanlığı kucaklamış, elit bir İslam devleti olduğudur. Bu itibarla Soğuk Savaş zamanında Türkiye'nin ABD'nin Ortadoğu bölgesindeki Jandarması algısı değişmiş elit bir İslam devleti görünümüne bürünmüştür. Artık Türk-Arap ilişkilerinde aşamalı bir yükseliş seyrettiği gözlemlenecektir. Beşer Esad'ın 2000'li yıllarda iktidara gelmesiyle ilişkiler normale dönmeye başlamış, karşıııkı ticaret hacminin fazlalaştırılması, sınır ticaretinin çoğaltılması gibi yaşanan gelişmeler iki ülke arasındaki ilişkileri hızlandırmıştır. Bu arada İran ile olan ilişkilerde hız kazanmış, doğalgaz alımı, mütekabiliyet çerçevesinde yatırım ve ticaret hacminin fazlalaştırılması, eğitim ve kültüre yönelik alanlarda ikili ilişkilerin daha da geliştirilmesi kararlaştırımıştır. 2008 yılının sonunda İran ile ticaret hacmimiz 7 milyar dolara ulaşmış ve İran Türkiye'nin 8. büyük ticari ortağı konumuna gelmiş olup, Türkiye, İran ve Brezilya'nın da dâhil olduğu uranyum takas anlaşması da ilişkilerimizin ne kadar geliştiğini göstermektedir. 2003 Mart tarihli 1. Tezkerenin reddi, Türkiye tarafından İsrail'in Filistin'e uyguladığı şiddetin İsrail devlet terörü olarak adlandırılması ve Davos zirvesinde "One Minute" çıkışı gibi yaşanan gelişmeler Türkiye'nin Ortadoğu da otonom bir düzen kurucu olarak aktif rolünü göstermektedir (Akıllı, 2012: 44).

Türkiye'de özellikle Arap Baharı öncesi 2009 yılı Mayıs ayında Dışişleri Bakanlığı'na getirilen Ahmet Davutoğlu, Türk dış politikasının şekillenmesi noktasında öncü isim olmuştur. Başbakan Erdoğan'ın 2009 yılında çözüm süreci, 2010 Anayasa halkoylaması gibi konular bu dönemde iç siyasete daha fazla ağırlık verdiğini gösterirken, Cumhurbaşkanı Gül'ün ise dış politikadaki münakaşalara statüsü gereği fazla bağlılık göstermeden yurt dışı geziler ve ziyaretler üzerinden yapılan açılımları pekiştiren bir role büründüğünden, Davutoğlu dış politikanın yapımına yön veren kişi olarak 
işin merkezi kısmına yerleşmiştir (Balcı, 2018: 3b 320). Ak Parti dönemi Türk dış politikasının bu bağlamda aydın tarafını ve kuramsal arka planını Ahmet Davutoğlu'nun yeniden şekillendirdiği söylenebilir. Davutoğlu'nun dış politika anlayışına göre üç adet yöntemsel ve beş adet de uygulamaya yönelik unsurlar bulunmaktadır. Bu unsurlar Türk dış politikasında evveliyat taşıyarak bu düsturlardan hareket edilmiştir. Üç adet yöntemsel unsurlar şunlardır; vizyon sahibi, tutarlı ve sistematik ve yumuşak güce dayalı yeni bir anlayıştır. Yöntemsel unsurların uygulamaya geçirilecek düsturlar şunlardır; güvenlik ve özgürlük dengesi, komşularla sıfır sorun, pro-aktif ve önleyici diplomasi, çok boyutlu-çok kulvarlı anlayış ve ritmik diplomasidir. Davutoğlu'nun dış politika anlayışında öne sürdüğü ve pratiğe dökmek istediği anlayıştan kendisinin aktif bir politika öngörmesi, Türkiye'nin özgüveni yüksek, köklü tarihsel geçmişe sahip olan, jeopolitik konumundan kuvvet alan bir devlet olduğunu kabul etmesinden kaynaklanmaktadır (Tarcan vd., 2018: 252-257). Türkiye Soğuk Savaş sonrası dönem dış politikasında hususiyetle Ortadoğu'da kendisine daha fazla güvenen ve gelişmelere pasif kalmayıp çözümler üretmeye çalışan bir yaklaşım sergilemiş olup, Ak Parti iktidarı ile birlikte bu gelişmeler dönüm noktasına ulaşmıştır. Geçmişte Arap dünyasının gözünde Türkiye, ABD'nin Ortadoğu jandarması gözüyle bakılırken Ak Parti döneminde Müslümanlığı kucaklamış ve seçkin bir İslam devleti hüviyetine bürünmüştür. İran ve Suriye ile ilişkiler inanılmaz bir biçimde artmış, Davutoğlu'nun anlayışıyla dış politika ayrı bir boyut kazanmış Türkiye ekonomi alanında önemli olan G-20'ye dâhil olmasından Ermenistan ile imzalanan protokole, komşularla sıfır sorun yaklaşımı ve Suriye ile olan sınırlarımızın kaldırılması boyutuna varan gelişmeler Arap Baharı öncesi dönüm noktasına ulaşmıştır.

\subsection{Arap Baharı İle Beraber Türkiye'nin Olaylara Yaklaşımı}

Türkiye, Ortadoğu bölgesinde meydana gelen Arap Baharı olaylarına karşı sergilediği duruş, bölgedeki yapılması muhtemel reformları ve demokrasiye yönelik atılacak adımları desteklemektedir. Komşularla sıfır sorun politikasına uygun olarak bölgede cereyan eden halk ayaklanmalarının dış politika menfaati ile çelişmediği görülmektedir (Sağsen, 2011: 61).

Türk Dış İşleri Bakanlığı'nın 2013 Mali Yılı Bütçe Tasarısının TBMM Genel Kuruluna sunulması vesilesiyle hazırlanan kitapçıkta:

"Dış politikamızın, çevremizde bir barış, istikrar ve refah kuşağı oluşturulması yönündeki temel hedefi çerçevesinde, çeşitli sorunlarla örülü Orta Doğu coğrafyası başlıca ilgi alanlarımızdan birini 
oluşturmaya devam etmektedir. Orta Doğu halklarıyla köklü tarihi, kültürel ve beşeri bağlarımız ve bölgedeki gelişmelerin Türkiye'ye doğrudan veya dolaylı etkileri, bizi bölge meselelerini çok yakından izlemeye mecbur kılan öğelerdir. Türkiye, bölgede kalıc barış ve istikrarın tesisi amacıyla elinden gelen her türlü katkıyı yapmaktadır" (Davutoğlu, 2012: 54).

ifadelerinde bulunulmuştur. Bu itibarla, Türk dış politikasının anlayışında, Türkiye'nin Arap Baharı ile olayları takip etmekten ziyade, olaylara karışan bir yaklaşım sergilediği görülmektedir. Başbakan Recep Tayyip Erdoğan ve Dışişleri bakanı Ahmet Davutoğlu defaatle, Cumhurbaşkanı Abdullah Gül'de ara ara, Mısır'da cereyan eden gelişmelerin başlangıcından itibaren süreçle ilgili geniş izahatlar yapmışlar ve kullandıkları sözlerde mevkidaşları olan Mısır, Libya ve Suriyeli devlet yöneticilerine nasıl adımlar atmaları gerektiği konusunda mutlak ve net sözler dile getirmişlerdir. Hususi olarak Arap halkları arasında geniş heyecan uyandıran ve takdirle karşılanan bu sözler ardından ferdi düzeyde Türk devlet yetkilileri ve genelinde Türkiye Cumhuriyeti Devleti ile ilgili bu politika sıcakkanlılık oluşturmuş ve müteaddit şekilde olumlu yaklaşımlar görülmüştür. Türkiye açısından, devletin en üst kademelerinden yapılan ve Arap halk isyanlarına kuvvetli destek veren izahatlarına sadece ferdi tercihler ve o dönemde gelişmelerin tesirinde yapılmış hissî açıklamalar olduğunu söylemek çokta doğru olmayacaktır. Batı demokrasi modelini özümsemiş ve halkının çoğunluğu Müslüman olan Türkiye'nin sadece bu yönüyle değil, Arap ülkeleri ile olan tarihsel bağları nedeniyle de diktatörlükleri sırayla yıkmaya başlayan halkların gönlünde dini ve kültürel hürlük ve demokratik yönetimi ile imrenilen bir ülke pozisyonuna dönüştüğünü söylemek yanlış olmayacaktır (Kibaroğlu, 2011: 31-32).

\subsection{Arap Baharı Sonrası Türkiye'nin Olaylara Yaklaşımı}

Ortadoğu bölgesi, Arap Baharı sonrası dönüşüm sürecine girmiş ve bölgedeki aktörleri bu bölgeye yönelik dış politikalarında yeniden ele almaya itmiştir. Türkiye 2011 yılı başlarında Arap Bahar'ını olumlu yönde içselleştirmiştir. Türk dış politikasının Arap Baharı ile ilgili genel perspektifi bölgedeki dönüşüm için alt tabakadan üst yönetim tabakasına doğru bir talep olduğu yönündedir ve Türkiye bu durumu Arap halkının istekleri olduğunu ve Türkiye'nin bu isteklerinin karşılığı olan desteği hak ettiği yönünde politika uygulamıştır (Kardaş, 2013: 71-79). 


\subsection{Türkiye'nin Tunus'ta Yaşanan Yasemin Devrimine Yaklaşımı}

Tunus'da 10 Ocak 2011 tarihinde olaylar başlamış, dört gün sonra da Türk Dışişleri Bakanlığı konu ile ilgili resmi bir açıklama yayımlamıştır. Açıklamada,

"Tunus'ta bir süredir devam eden gösteriler çerçevesinde meydana gelen, çok sayıda insanın hayatını kaybetmesine ve yaralanmasına neden olan olayları derin kaygı ve üzüntüyle karşılıyoruz"

denilmiş fakat Bin Ali'nin ülkesini terk etmesiyle ilgili herhangi bir beyanatta bulunulmamıştır. Açıklamanın devamında

"Bölgesinde önemli bir konuma sahip olan dost ve kardeş Tunus'ta mevcut gerginliğin daha da tırmanmaması, ülkede biran evvel asayiş ve huzurun yeniden tesis edilmesi içten temennimizdir." ifadelerinde bulunulmuştur (Dışişleri Bakanlığı, 2011; Koçak, 2013: 53).

Geçen süre içerisinde Türkiye tarafından 23 Ekim 2011 tarihine kadar Tunus ile ilgili herhangi bir açıklama yapılmamıştır. Dışş̧leri Bakanlığı tarafından Tunus Ulusal Kurucu Meclis seçimleri nedeniyle açıklamada bulunarak,

"23 Ekim tarihinde Tunus'ta düzenlenen Ulusal Kurucu Meclis seçimlerinin yüksek katılımla, demokratik ve barışçıl bir ortamda gerçekleştirilmiş olmasından memnuniyet duyuyoruz... Tunus'ta başlayan ve birçok bölge ülkesine de ilham kaynağı olan toplumsal değişim ve demokratik dönüşüm hareketine başından itibaren destek veren Türkiye, Ulusal Kurucu Meclis seçimlerinin hazırlıklarına katkıda bulunmuş, seçimleri izlemek üzere Tunus'a 10 kişilik bir Ulusal Gözlemci Heyeti göndermiş, buna ilaveten, AGİT Parlamenter Asamblesi, Avrupa Konseyi Parlamenter Meclisi ve İslam İşbirliği Teşkilatı heyetlerinde Türk gözlemciler yer almıştır. Türkiye, Tunus'taki demokratik dönüşüm sürecini bundan böyle de desteklemeye devam edecektir" (Dışişleri Bakanlığı, 2011) belirtmiştir.

İslami Eğilimli El-Nahda Hareketinin önderi Raşid Gannuşi'de Ak Partiyi örnek aldıklarını açıklamıştır. Bununla beraber Tunuslu idareci olan Ahmet Necip Cebbi, Tunus'un Türkiye'dekine benzer bir demokrasiyi benimsemesi gerektiğini dile getirmekte, ılımlı İslami siyasetçilerin ülke 
yönetiminde başarıyla hayata geçirilen katılımcı demokrasinin bulunduğunu, İslami kültürle batı demokrasi kültürünü bir araya getiren siyaseti yakından takip ettiklerini ve Türkiye'deki demokrasi modelini örnek aldıklarını izah etmiştir (Dışişleri Bakanlığı, 2011; Shadid, 2011). Türkiye'nin Tunus'ta yaşanan Yasemin Devriminde uyguladığı dış politikada ilk olarak olayı itidalle karşılamış, diktatör Bin Ali'nin ülkeden kaçması hususunda herhangi bir beyanatta bulunmamıştır. Bunun nedeni halkın taleplerine, demokrasiye geçişin sağlanmasına verdiği önemle beraber Türkiye'nin bölgede aktör ülke olarak yer almasını istemesinin bir gereği olarak belirtilebilir. Türk dış politikası açısından Tunus'un kendine has yapısı göz önünde bulundurularak olumlu ve yerinde bir yaklaşım sergilediği görülmektedir.

\subsection{Türkiye'nin Mısır'daki Devrime Yaklaşımı}

Türkiye, Arap Baharı olaylarının Mısır'a sıçramasıyla beraber, Mısır halkının yanında olduğunu ve desteğini aleni bir şekilde ortaya koymuştur. 03 Mart 2011'de Cumhurbaşkanı Abdullah Gül ve Dışişleri Bakanı Ahmet Davutoğlu Mısır'ı birlikte ziyaret etmiş, 13 Eylül 2011'de Başbakan Recep Tayyip Erdoğan Mısır'a ziyareti de Türkiye'nin ülke halkına olan desteğini pekiştirmiştir. Hatta Erdoğan bununla da yetinmeyip, Mısır'a uygun demokratik ve laik bir anayasasının olması gerektiğini, laikliğin dinden çıkma olarak görülmemesini belirtmiştir (Kirkpatrick, 2011). Diktatör Mübarek rejiminin devrilmesi ile beraber Türkiye Mısır'a yönelik üst düzey ziyaretlerle dış politikasında Mısır'a yönelik halk ayaklanmalarını ve halkın iradesiyle gelecek olan demokratik yönetimi desteklediğini ortaya koyarak, diktatör rejimden yana olmadığını, halkın iradesiyle demokratik yönetimin seçilmesi yönlü politika uygulamıştır.

30 Haziran 2012 yılında Mursi'nin Cumhurbaşkanı seçilmesiyle gelişen yeni süreçte Türkiye ile Mısır arasındaki münasebetler zirve noktasına ulaşmış, iki ülke arasındaki resmi ziyaretler ve ticaret antlaşmaları bu münasebetlerin boyutlarını göstermiştir. Türkiye, Mursi önderliğindeki Mısır'a pozitif bir yaklaşım sergileyerek karşılıklı olarak ziyaretlerini sıklaştırmışlardır. Türkiye dış politikasında, Mısır'ın bölgede yeniden oyun kuruculuğa bürünmesi ve yaşanan gelişmelere müdahale yetisini, Mısır'ı kendisine bir rakip olarak değerlendirmemiş bilakis, bölgede kendisine partner olarak görmesini sağlamıştır. Türkiye, Mısır'ı bölgede cereyan eden problemlere çözüm odaklı birlikte hareket edebileceği ve Türkiye'nin yükünü azaltacağı değerlendirilmiştir. Bölgede cereyan eden problemlere çözüm odaklı birlikte hareket eden ve Türkiye'nin bölgedeki yükünü azaltan bir ülke olarak nitelendirmiştir (Kaya, 2018: 474-476). 
Mısır'da 3 Temmuz 2013 tarihinde yapılan askerî darbe, Türkiye ve Mısır arasındaki ilişkileri ciddi bir şekilde etkilemiştir. Türkiye sivil toplum ve muhalefetiyle birlikte, Mısır'da, Mursi'ye karşı yapılan askerî darbeye sert bir tepki göstererek darbeyi kınamıştır. Mısır bu tepkiye karşı Türkiye ile diplomatik ilişki seviyesini düşürmüş, mütekabiliyet ilkesi gereği yapılan uygulamalar iki ülke arasındaki gerilimi tırmandırmıştır. Bu gerginlik iki ülke arasında ticari, askeri, siyasi ilişkileri önemli ölçüde etkilemiştir (Sarıarslan, 2019: 541-544). Erdoğan, Rabia meydanında yaşananları bir vahşet, el Sisi'yi de diktatör ve darbeci olarak nitelemesi, Türkiye, Mısır tarafından soruşturulan İhvan lider ve üyelerini ülkesinde kabul etmesine karşın Mısır bu durumu Türkiye'nin içişlerine karışması olarak nitelemiştir. Türkiye yapılan bu darbeyle Mısır'daki devrim sürecinin sonlandırılması hedefiyle yapılan bir hamle olarak değerlendirmiştir. Türkiye, Mısır'da yapılan bu darbe karşıtlığı politikası iki faktörden etkilendiğini göstermektedir. Birincisi, Türkiye siyasette Askerî darbelerden yana mustarip olması ve aynı halin bir daha yaşanmasından çekinmekte, ikincisi, Türkiye, Ortadoğu politikasında bölgede Mısır Ordusunun kendisine engel olacağı düşüncesinden kaynaklanmaktadır (Nouhy, 2017: 110-118). Türkiye Mısır'a yönelik dış politikasını darbe karşıtlığı ekseninde diğer Ortadoğu ve Türk-Arap ilişkileri bağlamında genel olarak değerlendirmiş, Mısır'ın kendine has özelliği göz önünde bulundurulmamıştır. Bu durum Türk dış politikasında hatalara, yanılmalara ve bunlar üzerine inşa edilmiş hassas olmayan davranış ve kararların alınmasına sebep olduğu söylenebilir.

\subsection{Türkiye'nin Bahreyn Değişimine Yaklaşımı}

Türkiye geneli itibariyle Arap Baharı olaylarında halkların yanında olduğunu açık bir şekilde sergilemiştir. Fakat Bahreyn'de meydana gelen olaylarda politik ve ticari sebeplerle ve problemin körfez ülkelerinin tamamını kapsamasından dolayı, olaylarla yakından alakadar olmamayı bir kaçış yolu olarak tercih etmek mecburiyetinde kalmıştır. Bu durum Türk dış politikasında kendi prensipleriyle ikilem oluşturmuştur. Bu hal yalnız Türkiye'nin değil Avrupa ülkeleri, $A B D$ ve batı ülkelerinin yüzleştiği bir problemdir. Türkiye'nin ve Batı'nın bu yaklaşımı, dış politika alanının ilkeler ve değerler üzerinden değil, menfaatler üzeri kurulduğunu göstermektedir (Öztürk, 2013: 364-365). Arap Baharı olayının farklı bir yansıması olarak Bahreyn'de Türkiye kendi menfaatleri gereği ülke ve bölge gerçeklerinden ötürü tutarsız yaklaşımlar sergilediğinden ortaya koyduğu idealist yaklaşımların Bahreyn üzerinde bir geçerliliğinin olmadığını göstermektedir. 


\subsection{Türkiye'nin Yemen Devrimine Yaklaşımı}

Türkiye, bölgeye yayılan Arap ayaklanmalarında Mısır ve Tunus'ta değişim için çok istekli ve çabuk bir tepki verirken aynı tepkiyi Yemen ve Libya'da göstermemiştir. Türkiye'nin bu dış politika anlayışı, ayaklanmalardan sonra bölgede ortaya çıkabilecek gruplaşmaların öngörüldüğünün göstergesidir. Ayrıca Türkiye, Sünni Suudi Arabistan ve Şii İran arasında gruplaşan, kutuplaşan Ortadoğu ve Kuzey Afrika ülkeleri arasında ilerideki ilişkilerini belirleyen etkenlerden biridir (Nouhy, 2017: 1314). Yemen bölgedeki diğer rejimlerden farklı tesirleri olan bir ülkedir. Yemen'de anayasal düzen içinde bir geçiş sağlanamazsa iç savaş kaçınılmaz olacağı, kuzey ve güney olarak bölünme riski göstereceği öngörülmektedir. Bu sebeple Körfez İşbirliği Konseyi Yemen'de anayasal bir değişikliğe gidilmesini savunurken Türkiye'nin de Yemen'e yaklaşımı bu yöndedir. Türkiye, Yemen ile ilişkilerini geliştirmeye çalıştığı için ülkenin bölünmemesi ve iç savaşın yaşanmamasını istemekte, iktidarın devrilmesinden ziyade anayasal bir geçişin sağlanmasını arzu etmektedir. Yemen'deki yönetimin Suudi Arabistan ve Mısır ile yakın ilişkide bulunması Türkiye'nin bu ülkeye bakış açısını değiştirmemektedir. Ancak Türkiye, Yemen'e uluslararası müdahalede bulunulmamasını ve yumuşak bir geçişin sağlanmasını ayrıca ülke ile ekonomik ilişkilerin geliştirilmesini amaçlamaktadır (Oktay, 2011).

\subsection{Türkiye'nin Tunus, Mısır, Bahreyn ve Yemen'e Yönelik Günümüz Dış Politikası}

Tunus'da 2014 yılında yeni anayasanın kabulüyle hükümet ülkeyi seçimlere götürdü, seçimlerden sonra diktatör Bin Ali yönetiminin işlediği suçların soruşturulması için komisyon teşkiline gidildi, bu çalışmalarda emeği olan Ulusal Diyalog Dörtlüsü'ne 2015 yılında Nobel Barış Ödülü verildi. Tunus'da yaşanan olayların darbeye dönüşmemesinde Nahda Hareketinin lideri Gannuşi'nin payı büyüktür. Gannuşi,

"Türkiye'yi bir model ülke olarak görüyoruz. Ekonomideki başarılarından, insan haklarından ve demokrasiden edindikleri kazanımlardan faydalanmak istiyoruz" ifadeleriyle Türkiye'nin Tunus'un dönüşümünde önemli bir ülke olacağını belirtmiştir (Gannuşi, 2012; Euronews, 2020).

Devrim zamanında Tunus halkının yanında yer alan Türkiye, devrimden sonra Tunus ile ticari ve siyasi ilişkileri önemli bir ivme kazanmıştır. 2018 yılında iki ülke arasında ticaret hacmi 1,1 milyar dolara kadar yükselmiş olup, 50'ye yakın Türk şirketi de Tunus'ta faaliyet göstermektedir. Tunus'ta 2019 yılı Eylül ve Ekim aylarında yapılan seçimin 
ardından 25 Aralık 2019 yılında Cumhurbaşkanı Erdoğan Tunus'a bir ziyaret gerçekleştirmesi Türkiye'nin dış politikası açısından Tunus'un jeopolitik ve jeostratejik konumu gereği, ziyaretin ayrı bir önemi bulunmaktadır. Türkiye, Yasemin Devriminde gösterdiği dış politikanın meyvelerini toplamaya başlamıştır. İki ülke arasında yaşanan gelişmelerle beraber Tunus, Libya meselesinde uzun bir zaman tarafsız kalmış, Mısır ile de siyasi ve sosyal ilişkilerini sınırlı tutarak, Mısır tarafından desteklenen Hafter'i destekler bir açıklamada da bulunmamıştır. Ayrıca Tunus Libya'nın batı sınır komşusu olup, Libya'nın batı sınırının güvenliğinin sağlanması hususunda Türkiye için ayrı bir önem taşımaktadır. Tunus'un hava sahasını ve limanlarının Türkiye'nin kullanımına açılması, Libya sınırları içerisinde meydana gelmiş veya gelmesi muhtemel kesintileri en az seviyeye indirecek, Libya sınırları dışındaki bir üs, Türk Ordusunun envanter güvenliğini de temin edeceği belirtilmektedir (Sakınan, 2020). Türkiye dış politikasında Yasemin Devriminde olduğu gibi 2019 yılında yapılan seçimlerden sonra da Tunus'a siyasi iktidar kazandırma gayreti içerisine girmiş, Tunus ile ilişkilerini geliştirerek uluslararası sorunlarda da iş birliğini artırma gayreti göstermiştir.

Mısır'da seçilmiş ilk Cumhurbaşkanı Mursi'nin darbeyle devrilmesinden sonra Türk Dışişleri Bakanlığı konu ile ilgili resmi bir açıklama yayımlamıştır. Sayfa | 368 Açıklamada,

"Türkiye ile Mısır arasındaki diplomatik ilişkiler 2013 yılından bu yana karşılıklı olarak maslahatgüzar düzeyinde sürdürülmekte, bununla birlikte iki ülke Dışişleri Bakanları arasında çeşitli vesilelerle kısa görüşmeler gerçekleştirilmekte, Mısırın Ankara Büyükelçiliğiyle İstanbul Başkonsolosluğu ve ülkemizin Kahire Büyükelçiliğiyle İskenderiye Başkonsolosluğu faaliyetlerine kesintisiz olarak devam etmektedir." ifadelerini kullanmıştır (Dışişleri Bakanlığı, 2018).

İki ülke arasındaki diplomatik ilişki böylece maslahatgüzar seviyesine düşürülmüştür. Bununla beraber siyasi krizler artarak devam etmiş, Mısır ile Türkiye arasındaki siyasi gerginlik, 05 Haziran 2017 yılında Suudi Arabistan, $B A E$, Bahreyn ile körfez dışından Mısır'ın da iştiraki ile Katar, havadan, karadan ve denizden ablukaya alınan ve tüm ilişkileri koparılan körfez krizinde de kendisini göstermiştir (Cengiz, 2018). Türkiye, Katar'a yönelik bu eylemden sonra Doha yönetiminin en büyük destekçilerinden birisi olmuş ve Ankara bu ülkeye en üst düzeyde ziyaretlerde bulunmuştur. Türkiye'nin Katar'a bu yönlü destek vermesinin önemli nedenlerinden birisi Katar'ın Mısır'daki darbeye karşı çıkması ve Müslüman Kardeşlere destek olmasından kaynaklanmaktadır. Bu yakınlaşma Ankara-Kahire arasındaki 
gerilimin devam etmesine Suriye ve Libya gibi konularda Türkiye'nin politikalarına karşı Mısır'ın hasimane bir politika izlemesine neden olmuştur (Telci, 2017: 213-220). Türk Dış politikasına ekonomik olarak iki ülke arasındaki ilişki bağlamında ele alındığında, Türkiye'nin ithalat-ihracat gelirleri kısmi dalgalanmalar olsa da siyasi krizden etkilenmediğini göstermektedir. Örneğin 2013 yılında ihracat geliri 3 milyar 200 bin dolar iken, 2014 yılında 3 milyar 300 bin dolar civarında olduğu, 2019 yılının ilk çeyreğine gelindiğinde ise 800 bin dolar bandında seyretmiştir. Türkiye ve Mısır arasında yaşanan siyasi gerginlik artarak devam ederken, ekonomik iliş̧iler de artan bir hızla devam etmiştir. Ekonomik ilişsilerin siyasi gerginliğe yansımamasına iki ülke de özen göstermeye çalışmıştır (Türk, 2018: 20-24).

Türkiye ve Mısır arasında 6 yıldır yaşanan kontrollü gerginlik, 18 Haziran 2019 tarihinde Mursi'nin mahkeme salonunda ölmesiyle en üst seviyeye tırmanmıştır. Cumhurbaşkanı Erdoğan, Mursi'nin ölümünü şüpheli olarak değerlenmesi ve Türk medyasının bu olayı yayınlamasıyla, Anadolu ajansı ve TRT'nin Arapça yayın yapan sitelerine Mısır yönetimi erişim yasağı uyguladı. Ardından Türkiye'nin 09 Ekim 2019 tarihinde Suriye'nin kuzeyine düzenlediği Barış Pınarı Harekâtını kınayarak, Arap Birliğini olağanüstü toplantıya çağırdı. 22 üyesi bulunan Arap Birliği, 10 ülkenin Dışişleri Bakanı Sayfa | 369 seviyesinde katılmasıyla Türkiye'nin düzenlediği harekât, Mısır'ın girişimleriyle kınanmıştır. İki ülke arasındaki 2019 yılının son gerginliği ise Türkiye ile Libya Ulusal Mutabakat Hükümeti arasında imzalanan "Güvenlik ve Askeri İşbirliği Mutabakat Muhtırası" olmuştur. Mısır Dışişleri Bakanı imzalanan anlaşmayı kınadığını izah etmiştir. Mısır Dışş̧leri Bakanı Samih Şükri ve Yunanistan Dışişleri Bakanı Nikos Dendias, Kahire'de bir araya gelerek imzalanan anlaşmanın gayr-ı meşru olduğunu açıklamışlardır. Türkiye 2020 yılı başında Libya'ya resmi hükümetin daveti üzerine asker göndermesi, Hafteri destekleyen Mısır tarafından hoş karşılanmamış, buna mukabil Anadolu ajansı Kahire bürosunun Mısır polisleri tarafından basılarak çalışanların gözaltına alınması, iki ülke arasındaki ilişkileri iyice gerginleştirmiştir (Kalabalık, 2020). Mısır Cumhurbaşkanı Sisi 20 Haziran 2020 tarihinde komşu ülke Libya'ya müdahale etmeye dair meşru bir hakka sahip olduğunu ve gerektiğinde Mısır Ordusunun ülke dışına yönelik bir görevi ifa etmeye hazır olmasını emretti. Sisi'nin politikası, bölgede rakibi olan Türkiye'nin Libya'ya dâhil olması ile yaşanan siyasi gerilimin bir neticesi olduğu düşünülmektedir. Mısır, Trablus'taki uluslararası kabul görmüş Ulusal Mutabakat hükümetine bağı orduyu, Halife Hafter'in doğu merkezli ordusu ile mevcut cephe hattını geçmemeleri konusunda uyardı. Türkiye'nin 
Ulusal Mutabakat hükümetine desteği, Rusya, BAE ve Mısır tarafından desteklenen Hafter'e bağlı ordunun Trablus'a yaptığı 14 aylık taarruzu tersine çevirdi. Sisi, Mısır'ın Libya sınırına yakın bir hava üssünü denetiminde "Mısır devletinin doğrudan müdahalesi artık uluslararası meşruiyet kazandı" ifadelerini kullanmıştır (The New York Times, 2020). Türkiye'nin Doğu Akdeniz'deki kıta sahanlığı ve bölgesel menfaatleri açısından Libya ile yapılan antlaşmalar önem arz etmektedir. Türkiye'nin Libya ile sürdürdüğü ilişki bölgede yaşanabilmesi muhtemel krizlerinde önüne geçmekte bölgede söz sahibi olabilmesinin önü açılmaktadır (Baygül, 2020: 163-164). Ayrıca Türkiye körfezdeki ülkelerle ekonomik, siyasi ve turizm ilişkilerine yönelik girişimlerini artırmakta fakat Türkiye-Mısır arasındaki siyasi kriz Türkiye'nin bu tür politikalarını olumsuz yönde etkilemektedir.

Bahreyn, Türkiye ile ilişkilerinde Suudi Arabistan'a tâbi siyasi profil çizen bir ülkedir. Bahreyn Veliaht Prensi Selman bin Hamad Halife'nin, 2015 yılı içerisinde Türkiye ve İran karşıtlığına yönelik bölgesel ittifak kurma yoluna gidilmesi iddiasıyla yapılan gizli bir toplantıya iştirak ettiği belirtilmektedir (Hearst, 2018). Bahreyn, körfez krizinde Katar'a yönelik uygulanan ambargoya da katılarak Türkiye karşıtı bir pozisyon sergilemiştir. Bahreyn Dışişleri Bakanı Şeyh Halid bin Ahmed bin Mohammed El Halife, Türkiye'nin Katar'daki üssünün bölgeyi koruma görevi olduğunu belirtmiş, fakat bölgeyi korumak için bir başkasına gerek olmadığını söyleyerek iki ülke arasında gerginliğe sebebiyet vermiştir. Diğer taraftan 2018 yılı Mayıs ayında Bahreyn Dışişleri Bakanı Halife'nin Twitter hesabından İran'ın bölgedeki mevcut durumu füzeleriyle tehdit etmeyi devam ettirdiği sürece, İsrail'in de aralarında yer aldığı bölge ülkelerinin de kendilerini savunma hakkının olduğu, yazılı beyanı Türkiye'nin Filistin'e yönelik politikasına zarar vermektedir. Körfez-İsrail yakınlaşma tutumu, Türkiye tarafından körfezde Katar ve Türkiye'nin etkisini yitirmesine yönelik bir adım olarak nitelendirilmiştir. Manama yönetiminin Suriye politikasındaki Türkiye karşıtlığı değişimi Ankara tarafından gerginliği artırma yönlü karşılanmıştır. 2018 yılı Ekim ayında Bahreyn Dışişleri Bakanı Halife'nin BM Genel Kurulu çalışmalarına iştiraki için New York'ta Suriye Dışişleri Bakanı Velid Muallim ile birlikte çok samimi pozlar verilmesi Ankara açısından Manama yönetiminin Esed yanlısı tutumu, zıt pozisyondaki Ankara'nın Manama yönetimine yönelik politikasına etki etmesi gerekmektedir. 2018 yılı Aralık ayında Bahreyn, Avustralya'nın Batı Kudüs'ü İsrail'in başkenti olarak tanıması kararını desteklerken, Arap Birliğinin bu karara yönelik tepkisini de eleştirmiştir. Türkiye ile Bahreyn arasındaki siyasi olumsuzluklara rağmen 
iki ülke arasındaki ekonomik alandaki ilişkiler olumlu yönde gelişme göstermektedir. Bahreyn Ekonomik Kalkınma Ajansının, finansal teknolojiler, yiyecek-içecek ve mühendislik kollarında faaliyet gösteren Türk şirketlerini ülkelerine yatırım yapmaları için davet etmiştir. Türkiye'nin Bahreyn'e yönelik ihracatı hızla artış göstermiştir (Rakipoğlu, 2018: 151153; Koyuncu, 2018). Türkiye'nin Suriye, Filistin politikaları ve Katar yönlü bölgesel kamplaşmadaki karşı duruşuyla da Bahreyn, Türkiye'ye siyasi gerginlik taşıması gereken bir yaklaşım sergilese de Türkiye ile ciddi siyasi bir gerginlik yaşamamıştır. Türkiye dış politikasında Mısır'a yönelik tutumunu Bahreyn üzerinde göstermemesi, körfez ülkelerine bakışında farklı politikalar uygulamaya çalıştığını, körfezde mevcut konumunu muhafaza etme tutumu gösterdiği ile açıklanabilir. Türkiye'nin bu yönlü politikasını anlamlandırmak mümkün görünmemektedir.

Yemen'de yaşanan iç savaş nedeniyle ülkede yaşayan insanların yarısından fazlası başta gıda olmak üzere insani yardıma muhtaç hale gelmiştir. Bir milyondan fazla ülke insanı dizanteri ve kolera gibi pandemi hastalığına yakalanmış, üç milyondan fazla ülke insanı yerleşim yerlerinden Yemen'in farklı bölgelerine göç etmek mecburiyetinde bırakılmıştır. En büyük felaketi çocuklar yaşamış olup, 2015-2018 yılları arasında 80 bini aşkın çocuk sefalet ve pandemi hastalıkları sebebiyle hayatını kaybetmiştir (Human Rights Whatch, 2019). Yemen, Suudi Arabistan ve İran'ın bölgedeki iktidar mücadelesini en açık bir şekilde yansıttığı ülkedir. Suudi Arabistan, İran yanlısı isyancı Husiler'in ülke üzerindeki hâkimiyetini kırmak için merkezi hükümet ve Körfez İşbirliği ülkeleriyle beraber 2015 yılında Kararlı Fırtına ve Altın Ok Harekâtını başlatmıştır. Türkiye bu harekâtı desteklemektedir. Türkiye, Suudi Arabistan'a Husiler tarafından yapılan füze saldırısını kınamış, ancak Suudi Arabistan'ın Yemende sebep olduğu insani felaketten de memnun kalmamıştır. Türkiye, Yemen'de İran-Suudi Arabistan mücadelesinin yol açtığı içler acısı yaraları iyileştirme yönlü bir dış politika sergilemiştir. Kızılay ve diğer sivil toplum örgütleri üzerinden Yemen'e yardımlar göndermiş ve göndermeye de devam etmiştir. Cumhurbaşkanı Erdoğan Yemen'e elli yataklı ağır iklim sahra hastanesini hibe etmiştir. Türkiye, İç savaş yaşanan Yemen'de meşru hükümeti destekleyen dış politika anlayışını sürdürmüştür (Rakipoğlu, 2018: 154). Ayrıca Yemen'in jeopolitik konumu Türkiye açısından ayrı bir önem taşımaktadır. Türkiye'nin Somali'deki askerî üssü ve Sudan'daki gözlem noktası ile Kızıldeniz jeopolitiğinde mühim bir aktör olduğunu göstermektedir. Bu nedenlerden ötürü Türkiye Aden körfezi ve Kızıldeniz'deki konumunun muhafazası için Yemen iç savaşının sona 
ermesinde etkisini göstermeye çabalamaktadır. Türkiye, Suudi Arabistanİran arasındaki çekişmeye taraf olmaktan imtina etmekte, bu ülkeler tarafından Yemen'e yapılan askerî operasyonları da tasvip etmemektedir. Türkiye, ülkede insani krize odaklanmış olup, bu içler acısı yaşanan savaşa eylem ve söylemleriyle müdahil olmaktadır (Domazeti, 2018). Bu bağlamda Türkiye yürüttüğü bu politika ile Suudi Arabistan ve İran arasında yaşanan krizin çözümünde bir arabulucu olabilir. Çünkü iki ülkeyi aynı masa etrafında toplayabilmek için İslami kimliği, geçmişe dayalı köklü, derin sosyal ve kültürel bağları bulunmaktadır. Suudi Arabistan ve İran arasında mevcut siyasal dengeler ve koşullarda uzlaşmadan yana bir pozisyon sergileyebilecek üçüncü taraf olarak siyasi arabuluculuk rolüne bürünebilir.

\section{SONUÇ}

Arap Baharı öncesi Türkiye'nin Ortadoğu bölgesindeki ticari, siyasi, sosyal ve kültürel ilişkiler dönüm noktasına ulaşmıştır. Arap Baharı ile beraber Türkiye'nin olaylara yaklaşımı halk ayaklanmalarının yanında yer alması ve diktatör rejimlerin yönetimi devretmesine yöneliktir. Türkiye'nin Arap Baharı ve sonrasına yönelik Tunus'a uyguladığı dış politikası meyvesini vermiştir. Tunus ile olan ilişkilerde Türkiye rol model ülke realitesini, yılların demokrasi tecrübesi, evrensel hukuk normlarına bağlılıkla ileri taşıma gayreti, kalifiye insan gücünü bu ülkeye aktararak hem Tunus yönetimi ile hem de halklarıyla samimi bağlarımızın sürdürülmesini sağlayacaktır. Tunus, jeopolitik ve jeostratejik konumu da düşünüldüğünde Akdeniz'de Türkiye'nin konumunu güçlendirmesine, kıta sahası güvenliğini sağlamasına, Libya'da yaşanan iç savaşın sona ermesine yönelik çabalarına da katkı sağlayacaktır. Uluslararası alanlarda ve sorunlarda iki ülke arasındaki sıkı iş birliği, Akdeniz'de Türkiye'nin yalnız olmadığı tezini de sağlamlaştıracaktır. Türkiye, Arap Baharı ve sonrasına yönelik Mısır'a uyguladığı dış politikasında istediğini alamamıştır. Türkiye, Doğu Akdeniz'de deniz sınırlarının güvenliği ve enerji kaynakları yönünden bölgeye yönelik sıkı ilişkiler kurmaktadır. Mısır, Türkiye'nin Ortadoğu bölgesindeki politikalarına hem set çekmeye çalışmakta hem de bölgede yalnızlığa sevk eden bir pozisyona düşürme çabasındadır. Türkiye, Katar ile ilişkilerini geliştirerek, körfezde de etkisini göstermek istemektedir. Fakat Mısır, körfez ülkelerinin dışında yer almasına rağmen, Suudi Arabistan, BAE, Bahreyn gibi ülkelerle kurduğu ittifak sayesinde Türkiye'nin bölgedeki etkisini yitirme gayretindedir. Türkiye-Mısır arasındaki siyasi gerginlik Ortadoğu ve Kuzey Afrika bölge politikalarını önemli ölçüde etkilemektedir. Türkiye, Doğu Akdeniz'de haklarını aramak için gerçekleştirdiği çabaların iki ülke arasındaki ilişkiler için bir anlam ifade edebilmesi için, Türkiye, Mısır 
yönetimi ile siyasi gerginliği bırakması gerekmektedir. Bu itibarla, iki ülke arasındaki ekonomik çıkarları başta olmak üzere kazan-kazan ilişkisinin temellerine yönelik cesur adımlar atmaları gerekmektedir. Çünkü Türk dış politikasının Mısır'a yaklaşımı kriz üzerine devam etmesi halinde Ortadoğu bölgesinde siyasi, askerî, sosyal, kültürel ve ticari ilişkileri ciddi şekilde zarar görmesi muhtemeldir. Türkiye'nin Arap Baharı ve sonrasına yönelik Bahreyn'e uyguladığı dış politikasında ikilem olduğu görülmektedir. Bahreyn'in Suudi Arabistan başta olmak üzere körfez ittifakı ile hareket ettiği düşünüldüğünde Türkiye, körfezde sadece Katar'ı koruyucu diğerlerini dışlayıcı bir politika gütmemelidir. Körfezde söz sahibi olabilmek için Katar ile körfez ülkeler arasında uzlaşmacı ve arabulucu röle bürünmesi bu bölgedeki etkisini artıracaktır. Türkiye'nin Arap Baharı ve sonrasına yönelik Yemen'e uyguladığı dış politikasında insani yaklaşım göstermektedir. Türkiye, Yemen'de iç savaşın çözümüne yönelik İslam İşbirliği Teşkilatı çatısı altında bazı çözümlere öncülük edebilir. Türkiye'nin Somali tecrübesi ve birikimi, Yemen'de de benzer bir süreci yürütebileceğinin göstergesidir. Türkiye, Yemen iç savaşının çözümüne yönelik Suudi Arabistan ve İran arasında uzlaşmacı ve arabulucu role bürünerek üçüncü bir aktör konumuna yükselme etkisi gösterebilecektir. Türkiye dış politikasında Tunus, Mısır, Bahreyn ve Yemen'in her birinin kendine has yapıları olduğu göz önünde bulundurularak, mevcut yönetimleri muhatap alması gerekmektedir. Bu ülkeler ile ticari, siyasi, sosyal, kültürel ilişkileri geliştirme çabası göstermelidir. Türkiye'nin mezhepsel yanılgıya düşmeden Müslüman kimliği bünyesinde bölgede aktif rol üstlenmesi bölgenin barış ve huzura kavuşmasına yönelik önemli bir katkı sağlayacaktır.

\section{KAYNAKÇA}

Akıllı, E. (2012). Türk Dış Politikası Zemininde Arap Baharı. Ortadoğu Analiz Dergisi 4(37), 39-45.

Anadolu Ajansı. (2017). Arap Bahar'ının Son Kalesi: Tunus. Erişim Adresi: https://www.aa.com.tr/tr/dunya/arap-baharinin-son-kalesitunus/1015340 Erişim Tarihi: 15.03.2020.

Anadolu Ajansı. (2020). Bir Diktatörün Bıraktığı Miras: Yavaş Yavaş Ölen Mısır. Erişim Adresi: https://www.aa.com.tr/tr/analiz/bir-diktatorunbiraktigi-miras-yavas-yavas-olen-misir/1751814 Erişim Tarihi: 20.03.2020.

Balcı, A. (2018). Türkiye Dış Politikası İlkeler, Aktörler ve Uygulamalar. İstanbul: Alfa Yayınları. 
Baygül, S. (2020). Değişen Uluslararası Konjonktür ve Türk Dış Politikası Bağlamında Libya İç Savaşı Analizi. Ankara Uluslararası Sosyal Bilimler Dergisi 3(6), 155-166.

Bekaroğlu, A. E. \& Kurt, V. (2015). Mısır'da Otoriter Rejimin Sürekliliği ve Ordu: 'Arap Baharı' ve Sonrası Sürecin Analizi. Türkiye Ortadoğu Çalışmaları Dergisi 2(2), 1-36.

Buzkıran, D. \& Kutbay, H. (2013). Arap Baharının Türkiye'ye Olan Ekonomik ve Sosyal Etkileri. Sosyal ve Beşeri Bilimler Dergisi 5(1), 147-162.

Catovic, S. (2015). Arap Bahar'ının Bir Başka Yansıması: Bahreyn. Erişim Adresi:

https://www.academia.edu/11007637/Arap Baharının bir başka yansım ası Bahreyn Erişim Tarihi: 28.03.2020.

Cengiz, H. (2018). Katar Krizi ve Körfez'deki Yeni İttifak Arayışları. Erişim Adresi: https://www.aa.com.tr/tr/analiz-haber/katar-krizi-ve-korfezdekiyeni-ittifak-arayislari/1189813 Erişim Tarihi: 27.06.2020.

Cicioğlu, F. \& Miş, N. (2013). Arap Baharı ve Yeni Ortadoğu. Bilgi Sosyal Bilimler Dergisi 2, 1-4.

Çelikkol, O. (2018). Yemende Neler Oluyor?. Erişim Adresi: https://www.hurriyet.com.tr/yazarlar/oguz-celikkol/yemende-neleroluyor-40879529 Erişim Tarihi: 01.04.2020.

Çiçekçi, C. (2012). Arap Baharı Sürecinde Türk Dış Politikasındaki Dönüşümün Anahatları. Erişim Adresi: https://www.academia.edu/1433816/Arap Baharı Sürecinde Türk Dıș P olitikasındaki Dönüşümün Anahatları Erişim Tarihi: 06.03.2021.

Davutoğlu, A. (2012). 2013 Yılına Girerken Dış Politikamız. Dışişleri Bakanlığı'nın 2013 Mali Yılı Bütçe Tasarısının TBMM Genel Kurulu'na Sunulması Vesilesiyle Hazırlanan Kitapçık, 1-155.

Dışişleri Bakanlığı. (2011). Tunus'ta Meydana Gelen Olaylar Hk. Erişim Adresi: $\quad$ http://www.mfa.gov.tr/no -14 -14-ocak-2011 -tunus tameydana-gelen-olaylar-hk .tr.mfa Erişim Tarihi: 22.06.2020.

Dışişleri Bakanlığı. (2011). Tunus Ulusal Kurucu Meclis Seçimleri Hk. Erişim Adresi: $\quad$ http://www.mfa.gov.tr/no 243 -28-ekim-2011 -tunus-ulusalkurucu-meclis-secimleri-hk .tr.mfa Erişim Tarihi: 23.06.2020.

Dışişleri Bakanlığı. (2018). Türkiye-Mısır Siyasi İlişkileri. Erişim Adresi: http://www.mfa.gov.tr/turkiye-misir siyasi-iliskileri-.tr.mfa Erişim Tarihi: 28.06.2020. 
Domazeti, R. (2018). Yemen Krizinin Çözümünde Türkiye Rol Alabilir Mi? Erişim Adresi: https://insamer.com/tr/yemen-krizinin-cozumunde-turkiyerol-alabilir-mi 1850.html Erişim Tarihi: 04.07.2020.

Duran, H. \& Özdemir, Ç. (2012). Türk Dış Politikasına Yansımalarıyla Arap Baharı. Akademik İncelemeler Dergisi 7(2), 181-198.

Euronews. (2020). Tunuslu Lider Gannuşi: Türkiye'yi Model Olarak Görüyoruz. Erişim Adresi: https://tr.euronews.com/2012/01/13/tunuslulider-gannusi-turkiye-yi-model-olarak-goruyoruz Erişim Tarihi: 29.06.2020.

Gün, M. S. (2012). Yemen'de Arap Baharı. Yasama Dergisi 22, 119-140.

Güvenç, C. (2020a). Sosyal Bilimlerde Yöntem Olarak Pozitivizm Bakış Açısı ve Değerlendirmesi. İşletme Ekonomi ve Yönetim Araştırmaları Dergisi 3(2), 109-120.

Güvenç, C. (2020b). Fransız Burjuva Devrimi: Bir Aydınlanma Hareketi Olarak Mutlak Monarşiden Cumhuriyete Geçiş. Kayseri Üniversitesi Sosyal Bilimler Dergisi 2(2), 64-73.

Güvenç, C. (2020c). Rousseau'cu Genel İrade Bağlamında Modern Devlet (Halk)'e Yönelik Bir Değerlendirme, Journal of Social Sciences and Humanities 4(2), 88-107.

Hearst, D. (2018). Ortadoğu'yu Yeniden Dizayn Eden Gizli Yat Gezisi, Türk Dış Politikası ve Ortadoğu Günlüğü. Erişim Adresi: http://ortadogugunlugu.blogspot.com/2018/03/dhearst-ortadogudasaflari-yeniden.html. Erişim Tarihi: 05.03.2021.

Human Rights Whatch. (2019). Yemen: Civilians Bombed, Shelled, Staved. Erişim Adresi: https://www.hrw.org/news/2019/01/17/yemen-civiliansbombed-shelled-starved Erişim Tarihi: 30.06.2020.

Kalabalık, A. (2020). Türkiye-Mısır İlişkilerinde 2019'da Kontrollü Gerginlik Hakimdi. Erişim Adresi: https://www.timeturk.com/turkiye-misiriliskilerinde-2019-da-kontrollu-gerginlik-hakimdi/haber-1326496 Erişim Tarihi: 01.07.2020.

Kardaş, Ş. (2013). Türkiye'nin Ortadoğu Politikasındaki Değişiklikler. Hazar Raporu 1, 71-79.

Kaya, E. \& Hasar H. (2012). Arap Dünyasında Entropi: Tunus, Mısır, Libya ve Suriye'de Halk Ayaklanmaları. Erişim Adresi: https://www.yumpu.com/tr/document/read/11907685/arap-dunyasndaentropi-tunus-msr-libya-ve-suriyede-tuic Erişim Tarihi: 30.04.2020. 
Kaya, E. E. (2018). 2000'li Yıllardan Günümüze Türkiye-Mısır Siyasi ve Ekonomik İlişkilerinin Seyri. (Ed.). M. Ercan. 21. Yüzyılda Küresel ve Bölgesel Aktörler Bağlamında Türk Dış Politikası içinden İstanbul: Efe Akademi Yayınları.

Kibaroğlu, M. (2011). Arap Baharı ve Türkiye. Adam Akademi Dergisi 2, 2636.

Kirkpatrick, D. D. (2011). Premier of Turkey Takes Role in Region. Erişim Adresi:

https://www.nytimes.com/2011/09/13/world/middleeast/13egypt. html?se archResultPosition=8 Erişim Tarihi: 25.06.2020.

Koçak, K. A. (2012). Yasemin Devrimi'nden Arap Bahar'ına Tunus. Yasama Dergisi 22, 22-61.

Koyuncu, H. (2018). Bahreyn'den Batı Kudüs'ü İsrail'in Başkenti Olarak Tanıyan Avustralya'ya Destek. Erişim Adresi: https://tr.euronews.com/2018/12/16/bahreyn-den-bati-kudus-u-israil-inbaskenti-olarak-taniyan-avustralya-ya-destek Erişim Tarihi: 03.07.2020.

Muslu, E. (2011). Yemen 2011, Ortadoğu Yıllığı Dergisi, Erişim Adresi: https://ormer.sakarya.edu.tr/uploads/files/oy2012 323 358.pdf, Erişim Tarihi. 05.03.2021.

Nouhy, A. A. (2017). Arap Baharı ve Türkiye-Avrupa Birliği İlişkileri. Ortadoğu Analiz Dergisi 4(48), 10-19.

Nouhy, E. A. A. (2017). Arap Baharı Sonrası Türkiye'nin Mısır Yumuşak Gücü. (Yüksek Lisans Tezi). Erişim Adresi: https://dergipark.org.tr/tr/pub/akademikincelemeler/issue/1546/18992

Oğuzlu, T. (2011). Arap Baharı ve Yansımaları. Ortadoğu Analiz Dergisi 3(36), 8-16.

Oktay, S. (2011). Yemen'deki Gelişmeler Ankara'nın Takibinde. Erişim Adresi: $\quad$ https://www.dw.com/tr/yemendeki-geli\%C5\%9Fmelerankaran\%C4\%B1n-takibinde/a-15418369 Erişim Tarihi: 26.06.2020.

Örtlek, M. (2013). Bahreyn'e Arap Baharı Gelir mi?. Sosyal ve Beşeri Bilimler Dergisi 5(2), 267-277.

Özdem, A. G. (2016). Büyük Devletlerin Değişmeyen Mücadele Alanı: ORTADOĞU. Fırat Üniversitesi Ortadoğu Araştırmaları Dergisi 10(2), 1-39.

Öztürk, A. (2013). Bahreyn 2013, Ortadoğu Yılığı Dergisi. Erişim Adresi: https://ormer.sakarya.edu.tr/uploads/files/bahreyn 2013.pdf Erişim Tarihi: 05.03.2021. 
Paksoy, S. Paksoy, H. M. \& Alancioğlu, E. (2013). Küreselleşmenin SosyoPolitik Etkileri: Arap Baharı. Elektronik Sosyal Bilimler Dergisi 12(46), 169182.

Rakipoğlu, M. (2018). Türkiye'nin Körfez Ülkeleri ve Yemen Politikası 2018. Türk Dış Politikası Yıllığı Dergisi. Erişim Adresi: https://setav.org/assets/uploads/2019/04/TDPY 2018.pdf Erişim Tarihi: 05.03.2021.

Sağsen, İ. (2011). Arap Baharı, Türk Dış Politikası ve Dış Algılaması. Ortadoğu Analiz Dergisi 3(31-32), 57-64.

Sakınan, H. (2020). Tunus'un Yakın Tarihi ve Türkiye-Tunus İlişkileri. Erişim Adresi: $\quad$ https://www.stratejikortak.com/2020/01/tunus-tarihi-turkiyeiliskileri.html Erişim Tarihi: 29.06.2020.

Sakin, S. \& Deveci, C. (2011). Ortadoğu Kavramı ve Sınırları Üzerine Bir Değerlendirme. International Journal of History 3(Özel Sayı), 281-293.

Sarıarslan, F. (2019). Türkiye-Mısır İlişkilerinde Ekonomik Dinamiklerin Etkisi. Erciyes Üniversitesi İktisadi ve İdari Bilimler Fakültesi Dergisi 54, 526-559.

Sarp, Ç. \& Cihan, M. (2020). Ortadoğu'da Müdahalecilik ve Egemenlik. Akademik Hassasiyetler Dergisi 7(13), 1-19.

Shadid, A. (2011). Tunus Demokratik Bir İslami Gelecek Hayal Ediyor. Erişim Adresi: http://www.nytimes.com/2011/10/20/world/africa/rachidal-ghannouchi-imagines-democratic-future-for-

tunisia.html? $r=1 \&$ ref=todayspaper\&pagewanted=print Erişim Tarihi: 24.06.2020.

Tarcan, B., Akgüller, H. \& Işık, K. (2018). Ahmet Davutoğlu Dönemi Türk Dış Politikası. Econder Uluslararası Akademik Dergisi 2(2), 250-271.

Telci, İ. N. (2017). Türkiye'nin Mısır Politikası. Türk Dış Politikası Yıllığı Dergisi, Erişim Adresi: https://tdpyilligi.setav.org/tdp/turk-dis-politikasiyilligi-2017.pdf, Erişim Tarihi: 05.03.2021.

The New York Times. (2020). Sisi: Mısır'ın Libya'ya Meşru Müdahale Etme Hakkı Var. Erişim Adresi: https://www.nytimes.com/reuters/2020/06/20/world/europe/20reuterslibya-security-egypt.html?searchResultPosition=1 Erişim Tarihi: 05.07.2020.

Turhan, T. (2012). Küresel İhanetin İç Yüzü ve Arap Baharı. İstanbul: Destek Yayınevi. 
Türk, K. (2018). Ak Parti Dönemi Türkiye-Mısır İlişkileri. TOBB Ekonomi ve Teknoloji Üniversitesi Dergisi. Erişim Adresi: https://www.academia.edu/38272744/AK Parti Dönemi Türkiye Mısır İli şkileri pdf Erişim Tarihi: 05.03.2021.

Yılmaz, H. İ. (2016). Ortadoğu'nun Jeo-Ekonomik Önemi ve ABD'nin Ortadoğu Politikasının Ekonomik Nedenleri. Tesam Akademi Dergisi 3(1), 99-128.

GENişLETİLMİ̧̧ ÖZET: Arap Baharı, Tunus'ta başlamış Kuzey Afrika ve Ortadoğu ülkelerinin tamamına yakınında önemli bir etki alanı yaratmışır. Tunus ve Mısır'da diktatör idarecilerin yönetimden el çektirilmesine, Bahreyn'de Batılı ülkeler ve körfez ülkelerin himayesinde diktatör yönetimin isyanı bastırmasına ve Yemende iç savaşın devam etmesiyle sonuçlanmıştır. Batılı devletler, Ortadoğu bölgesindeki enerji kaynaklarına sahip olma isteği bu bölgenin vazgeçilmez stratejik önemini ifade etmektedir. Bölge, petrolde olduğu gibi dünya doğalgaz rezervlerinin yarısına yakınına da sahiptir. Ortadoğu tarihi açısından Arap Baharı ayrı bir önem taşımaktadır. Arap Baharı, batılı ülkelerin yenidünya düzeni gayesiyle I. Dünya Savaşı'ndan günümüze planlarının bir parçasıdır (Sarp ve Cihan, 2020: 7-8; Turhan, 2012: 259; Yılmaz, 2016: 101). Ayrıca Ortadoğu, jeopolitik konumu ve sosyo-kültürel özellikleriyle, uygarlıklar meydana getirmiş, medeniyete beşiklik etmiş ve uygarlık tarihini de ortaya çıkarmıştır. Üç büyük dinin Yahudilik, Hıristiyanlık ve İslamiyet'in doğup büyüdüğü ve dünyaya yayıldığı bir bölgedir. Arap Bahar'ını, Ortadoğu'da baskı kuran ve otoriter yöneticilere karşı yakın dönemde ortaya çıkan halk ayaklanmalarını göstermek ve süreci demokratikleşme hareketi olarak tanımlayabiliriz. Arap ülkelerinde halkların işsizlik, yoksulluk, gelir dağılımındaki adaletsizlik gibi nedenlerin yanında baskıcı yönetimlerden dolayı bu bölgede demokrasi gelişme gösterememiştir. Tüm bu sebeplerden ötürü Arap Baharının ilk kıvılcımı Tunus'ta bir gencin kendisini yakmasıyla başlamış, bu ayaklanmaların ana nedenleri olan halkın açlık ve sefaleti, yoksulluğu, işsizliği gibi nedenlerden iyice bunalan halka yeniden diriliş için isyan hareketleri başlatmasına sebep olmuş, diktatör Zeynel Abidin Bin Ali rejimi devrilmiştir (Kaya ve Hasar, 2012: 9-12). Diğer ülkelerde Arap Baharı ile başarılamayan ve toplumun tüm kesimlerinin ortak ürününü yansıtan anayasa kabulü ile beraber Tunus'ta demokrasiye geçiş mümkün olmuştur (Anadolu Ajansı, 2017). Tunus'un ardından Arap Baharının sıçradığı diğer ülke de Mısır'dır. Tarih sahnesinde Mısır, 1953 yılında cumhuriyete geçmiş, fakat askerî yapı yönetimden hiçbir zaman vazgeçmemiş olup, Mısır yönetiminde otoriter ve baskıcı idarecilerin vesayetçisi Mısır ordusu olmuştur (Anadolu Ajansı, 2020). 25 Ocak 2011 yılında Tahrir Meydanında öfke gününde demokrasi çanlarının sesleri yankılanmış ardından özgür seçimler yapılmış Mursi seçimi kazanmıştır. Ancak Mursi'nin yaptıklarından veya yapacaklarından korkan muhalefet sokaklara dökülmüş Mursi taraftarları da sokağa dökülünce ortalık savaş alanına dönüşmüş, bunu fırsat bilen ve tarihteki görevini unutmayan iktidarın vesayetçisi Mısır ordusu yine yönetime el koymuştur 
(Bekâroğlu ve Kurt, 2015: 29). Arap Baharının yaşandığı diğer bir ülkede Bahreyn'dir. Tarihsel süreçte İngiltere'nin egemenliğinden kurtulup, 1971 yılında bağımsızığını ilan etmiştir. Ülkenin çoğunluğunu Şiiler oluştursa da yönetim Sünni olan Al Khalife ailesindedir. Arap Baharı ile beraber Bahreyn'in başkenti Manama'da İnci Meydanında toplanan halk protestolara başlamış ancak Suudi Arabistan liderliğindeki Körfez İşbirliği Konseyi ülkedeki eylemleri şiddetli bir şekilde bastırmıştır. Bahreyn'de her zaman Suudi Arabistan ve İran gerginliği yaşanmaktadır. Arap Baharı Bahreyn'e demokrasiyi getiremediği gibi çatışmaların bitmesini de sağlayamamıştır (Örtlek, 2013: 269; Catovic, 2015: 8-18). 2011 yılının Ocak ayında başlayan ve yıl boyunca tesiri altına alan Arap Baharının yaşandığı diğer bir ülke de Yemen'dir. Başkent Sana'da başlayan gösterilen hızla diğer illere de yayılmıştır (Muslu, 2011: 328). Ülkedeki mezhep kavgası, iç savaş, Arap Baharı gösterileriyle Suudi Arabistan önderliğindeki körfez ülkelerinin olaylara müdahalesi, Suudi Arabistan ve İran arasındaki çekişme gibi nedenlerden ve kolera gibi salgın hastalıklardan dolayı Yemende tam bir insani felaket yaşanmakta, yaşanmaya da devam etmektedir. Bu nedenlerden ötürü Yemende Arap Baharı kışa dönüşmüştür (Gün, 2012: 125; Çelikkol, 2018). Türkiye, bölgede jeopolitik ve jeostratejik bir konuma sahiptir. Tarihi köklü geçmişi, demokratik-laik yapısı, anayasal düzene bağlı bir hukuk devleti olması ve Müslüman kimliğinin bulunması nedeniyle bölgede model ülke olunabilecek bir konumdadır. Özellikle Ak Partinin 2002 yılında iktidara gelmesi ve Arap ülkeleriyle diplomasi trafiğini ticari, siyasi, kültürel ve sosyal olarak arttırmasıyla birlikte Arap ülkelerinin Türkiye'ye karşı Sayfa | 379 bakış açılarının olumlu yönde değişmesine sebebiyet vermiştir. Arap Bahar'ının başlamasıyla beraber Türk dış politikasının, bölgeye yönelik genel yaklaşımı, halk ayaklanmalarının yanında yer alması ve diktatör rejimlerin yönetimi devretmesi yönlüdür. Fakat Arap Baharı sonrasında yaşanan siyasi gelişmeler ile beraber Türkiye'nin Tunus, Mısır, Bahreyn ve Yemen'e yönelik dış politikasında farklı yaklaşımlar sergilediği görülmektedir. Türkiye'nin bahsi geçen bölge ülkelerine yönelik bu tutumu, kimi zaman bölgede yalnız kalmasıyla ittifak arayışlarına girmesine kimi zaman da Arap Bahar'ını yaşayan ülkenin diktatör rejimden, demokratik rejime yerleşmesine katkıda bulunmuştur. Bu çalışmada Ortadoğu'da yaşanan Arap Baharı öncesi ve sonrasında, Türkiye'nin Tunus, Mısır, Bahreyn ve Yemen örnekleri üzerinden olaylara bakış açısı ve yaklaşımı araştırmanın konusunu teşkil etmektedir. Bu noktadan hareketle; Türkiye, Arap Baharının başlamasıyla bölgede yaşanan gelişmelerde ortaya koyduğu politikayla ülke bazında farklı tutumlar sergilemesinin Türkiye açısından hangi siyasi sonuçlara sebebiyet verdiği ortaya konulması amaçlanmaktadır. Nitekim çalışmada, Arap Baharının yaşanmasıyla bölgede etkin rol alan Türkiye'nin ülkeler bazında karşılaştığı sorunlar ve olaylar irdelenmiş ve gelinen noktada bazı ülkelerle sorunların devam ettiği ifade edilmiştir. Nihai olarak Nitel yöntemin hâkim olduğu çalışmada Türkiye'nin bölgeye yönelik dış politika anlayışına değerlendirme ve yorumlama da bulunulmuş, ileriye yönelik Türk dış politikasının bölge üzerinde etkin rol sahibi olması yönlü katkı sağlanması hedeflenmektedir. 
EXTENDED ABSTRACT: The Arab Spring, which began in Tunisia, has created a significant sphere of influence near all the countries of North Africa and the Middle East. In Tunisia and Egypt, it resulted in the removal of dictator rulers from the administration, in Bahrain, the suppression of the dictatorship under the auspices of Western countries and Gulf countries, and the continuation of the Civil War in Yemen. Western states, the desire to have energy resources in the Middle East region express the indispensable strategic importance of this region. As with oil, the region has close to half of the world's natural gas reserves. From the point of view of the history of the Middle East, the Arab Spring has a separate significance. The Arab Spring, with the aim of the New World Order of Western countries. It is part of their plans from World War II to the present (Sarp and Cihan, 2020: 7-8; Turhan, 2012: 259; Yilmaz, 2016: 101). In addition, the Middle East, with its geopolitical position and socio-cultural characteristics, has created civilizations, become the cradle of civilization and revealed the history of civilization. It is a region where the three major religions Judaism, Christianity and Islam are born and raised and spread around the world. We can describe the Arab Spring as a movement for democratization, showing the popular uprisings that have been oppressing and emerging recently against authoritarian rulers in the Middle East. In Arab countries, democracy has not been able to develop in this region due to repressive administrations, as well as reasons such as unemployment, poverty, and injustice in the distribution of income of peoples. For all these reasons, the first spark of the Arab Spring started in Tunisia a young man Sayfa | 380 burn himself out, which is the main cause of the uprising poverty, hunger and misery, poverty, unemployment caused thoroughly depressed for reasons such as Resurrection people rebel movements to initiate a dictator is overthrown the regime of Zine El Abidine Ben Ali (Rock and consequential damages, 2012: 9-12). The transition to democracy in Tunisia has been possible with the adoption of a constitution that has not been achieved with the Arab Spring in other countries and reflects the common product of all segments of society (Anadolu Agency, 2017). After Tunisia, the other country where the Arab Spring jumped IS Egypt. In the historical scene, Egypt passed to the Republic in 1953, but the military structure never gave up Administration, and the Egyptian army became the custodian of authoritarian and repressive rulers in the Egyptian administration (Anadolu Agency, 2020). On January 25, 2011, Mursi won the election after the sounds of democracy bells echoed in Tahrir Square on a day of anger. But the opposition, afraid of what Morsi did or would do, took to the streets, and when Morsi's supporters poured into the streets, everything turned into a battlefield, and the Egyptian army, the custodian of power, who knew this opportunity and did not forget its mission in history, again seized power (Bekaroglu and Kurt, 2015: 29). Another country experiencing the Arab Spring is Bahrain. It was liberated from British sovereignty in the historical process and declared its independence in 1971. Although Shiites make up the majority of the country, the administration is in the Al Khalifa family, which is Sunni. With the Arab Spring, public protests began in 
Manama, the capital of Bahrain, but the Saudi-led Gulf Cooperation Council violently suppressed actions in the country. There is always tension between Saudi Arabia and Iran in Bahrain. The Arab Spring did not bring democracy to Bahrain, nor did it ensure the end of conflicts (Örtek, 2013: 269; Catovic, 2015: 8-18). Another country that experienced the Arab Spring, which began in January 2011 and took effect throughout the year, is Yemen. It started in the capital Sana and spread rapidly to other provinces (Muslu, 2011: 328). Due to sectarian strife in the country, civil war, Arab Spring demonstrations and the intervention of Gulf countries led by Saudi Arabia, strife between Saudi Arabia and Iran, and epidemics such as cholera, Yemen is experiencing and continues to be a complete humanitarian disaster. For these reasons, the Arab Spring in Yemen has turned into winter (Day, 2012: 125; Celikkol, 2018). Turkey has a geopolitical and geostrategic position in the region. It is in a position to be a model country in the region due to its historical deep-rooted history, democratic-secular structure, the fact that it is a rule of law related to the constitutional order and the presence of a Muslim identity. Especially since the Ak Party came to power in 2002 and increased diplomatic traffic with Arab countries commercially, politically, culturally and socially, it has led to a positive change in the perspectives of Arab countries towards Turkey. With the beginning of the Arab Spring, Turkish foreign policy has a general approach to the region, its participation in popular uprisings and the transfer of power by dictatorial regimes. But with the political developments after the Arab Spring, Turkey seems to have taken different approaches to its foreign policy towards Tunisia, Egypt, Bahrain and Yemen. Turkey's attitude towards the countries of the region has contributed to the country's establishment from the dictatorial regime to the democratic regime, which has experienced the Arab Spring, sometimes by being alone in the region and seeking an alliance. In this study, Turkey's perspective and approach to events before and after the Arab Spring in the Middle East through the examples of Tunisia, Egypt, Bahrain and Yemen are the subject of research. Based on this point, it is aimed to reveal what political consequences Turkey has caused by the policy it has put forward in the developments in the region with the beginning of the Arab Spring and the fact that it has shown different attitudes on a country-by-country basis. As a matter of fact, in the study, the problems and events faced by Turkey, which played an active role in the region with the experience of the Arab Spring, were examined and it was stated that the problems with some countries continued at the moment. As a result, the study dominated by the qualitative method also found an assessment and interpretation of Turkey's understanding of foreign policy for the region, and it is aimed to contribute to the fact that the Turkish foreign policy for the future has an active role in the region. 